Law in the Digital Age. 2021. Vol. 2, no. 3.

Вопросы права в цифровую эпоху. 2021. Т. 2. № 3.

\title{
Comment
}

Research article

УДК 347.77

DOI: $10.17323 / 2713-2749.2021 .3 .168 .178$

\section{Review of Key Positions of the Presidium of Intellectual Property Court of the Russian Federation}

\section{凡 Natalia Kapyrina', Maria Kolzdorf'2}

${ }^{1}$ MGIMO University, Moscow, Russia, Researcher ID: AAQ-3784-2021, n.kapyrina@ my.mgimo.ru, ORCID: 0000-0003-1276-1600,

${ }^{2}$ National Research University Higher School of Economics, Moscow, Russia, Researcher ID: AAI-1625-2019, mkolzdorf@hse.ru, ORCID:0000-0003-3227-3348

\section{眈国 Abstract}

The comment reviews key positions issued in the rulings of September and October 2021 by the Presidium of the Russian Intellectual Property Court (IPC). This Chamber hears cassation appeals against the decisions of the IPC first instance and deals primarily, but not only, with matters of validity of registered intellectual property rights. Therefore, this review primarily deals with substantive requirements for patent and trademark protection, as well as with procedural issues both in the administrative adjudicating mechanism at the Patent office (Rospatent) and at the IPC itself. The current review covers such issues as appeals against patent term extension (supplementary patent), appeals against partial refusals of trademark applications, distinctive character of trademark elements, a party's interest in judicial proceedings on unfair competition involving trademarks, and conflicts between trademarks and company names.

\section{0-1国 Keywords}

Russia, case-law, Intellectual Property Court, Rospatent, supplementary patent, trademarks, company names, unfair competition, procedure 
For citation: Kapyrina N.I., Kolzdorf M.A. Review of Key Positions of the Presidium of the Intellectual Property Court of the Russian Federation. Legal Issues in the Digital Age. 2021, no 3, pp. 168-178. DOI: 10.17323/2713-2749.2021.3.168.178

\section{Contesting supplementary patent}

A supplementary patent certifying the extension of the term of validity for an exclusive right, which has been granted in violation of the conditions stipulated in Art. 1363, para. 1(2) of the Civil Code of the Russian Federation (CC RF), may be contested in the Intellectual Property Court by an interested person on the basis of Art. 1398, para. 1(1) of the CC RF.

Decision of the Presidium of the IPC dated 18 October 2021 in case No. SIP-461/2020.

At present in accordance with Art. 1363, para. 2(1) of the CC RF, in the event that more than five years have elapsed from the date of filing a patent application for an invention related to such products as medications, pesticides, or agro-chemicals whose use requires obtaining permission through a procedure established by law, then the term of validity for exclusive rights to such an invention and of the certification of the right of patent is to be extended upon the application of the patent holder to the federal executive authority for intellectual property (Rospatent).

Pursuant to the current version of Art. 1363, para. 2(5) of the CC RF, upon extension of the term of validity for an exclusive right, a supplementary patent is to be issued in a format which includes all the features of the patented invention which are characteristic of the product for which permission to use the invention has been obtained.

Therefore, the basis for considering issuance of a supplementary patent is the application of the patent holder; however, the conditions for issuing it (i.e. extension of legal protection for a particular product) include:

a product such as a medication, pesticide, or agro-chemical whose use requires obtaining permission though a procedure established by law with that permission protected by a patent on an invention (hereinafter basic patent);

permission for the use of that product;

absence of any prior permissions to use that product;

expiration of more than five years from the date of filing for issuance of the basic patent until the receipt of such permission. 
Pursuant to the current version of Art. 1363, para. 5 of the CC RF, a supplementary patent may be deemed invalid on the grounds and through the procedure stipulated in Art. 1398 of the CC RF.

In accordance with Art. 1398, para. 1(1) of the CC RF, a patent for an invention, utility model, or industrial design may be deemed invalid in its entirety or in part, including in the event that the invention, utility model, or industrial design does not conform to the conditions for patent eligibility as prescribed by the CC RF.

The general conditions for an invention to be eligible for a patent apply both to the invention under the basic patent and also to the product under the supplementary patent and are stipulated by Art. 1350 of the CC RF. In addition, Art. 1363, para. 2(1) specifies the conditions for issuing a supplementary patent and also identifies the potential legal protections for a product under a supplementary patent. However, the legislature has not made the provisions of Art. 1398, para. 1(1) of the CC RF consistent with Art. 1363, para. 5 of the CC RF. Art. 1398, para. 1(1) does not take into account the possibility of contesting supplementary patents, nor does it acknowledge that such patents are subject to special conditions for their issuance pursuant to Art. 1363 para. 2(1) of the CC RF.

Art. 1363, para. 5 of the current CC RF indicates that a supplementary patent is subject to contestation on the grounds specified by Art. 1398 of the CC RF, but no such grounds are stated in Art. 1398 of the CC RF. Art. 1398, para. 1(1) of the CC RF is applicable to a supplementary patent merely to the extent that the basic patent may be contested; however, in breach of Art. 1363, para. 5 of the CC RF, no grounds for contesting a supplementary patent as such are specified. This situation indicates a gap in legislative regulation (Art. 6 of the $\mathrm{CC} \mathrm{RF}$ ) with respect to the grounds for contesting supplementary patents.

Issuance of a supplementary patent affects third parties that may have a private interest in using a technical solution after the expiration of the statutory term of validity for a basic patent, and it has an impact on an indefinite group of persons by impeding scientific advances and the activities of third parties in employing technical solutions that have devolved into the public domain. Issuance of a basic patent has the same consequences.

The public interest lies in ensuring that unlawful issuance of patents does not impede scientific advances or usage by third parties of technical solutions which are not eligible for protection, and that interest persists so long as the patent remains valid or may possibly be renewed. In that sense, 
the ability to contest an unlawfully issued supplementary patent has the same significance as the ability to contest a basic patent because a supplementary patent extends the term of the basic patent as it applies to a product covered by an invention under the basic patent.

As already noted above, the legal significance of the general conditions for eligibility of inventions (Art. 1350 of the CC RF) and the special conditions for eligibility of a product as such for a supplementary patent (Art. 1363, para. 2(5) of the CC RF) are identical - and both stipulate the conditions for a patent and for the term of its validity. Hence, the legal relations that arise from these legal standards are analogous.

The ability to contest supplementary patents is not only not in conflict with the essence of those relations but also explicitly stipulated by current law (Art. 1363, para. 5 of the CC RF). Consequently, the Presidium of the Intellectual Property Court is maintaining that a supplementary patent issued in violation of Art. 1363, para. 2(1) may be contested; by analogy, the applicable laws are Art. 6 (1) and Art. 1398, para. 1(1) of the CC RF.

The ability to verify the conformity of a supplementary patent with the special conditions for its issuance (Art. 1363, para. 2(1) of the CC RF) is guaranteed by Art. 46 of the Constitution of the Russian Federation and may not be restricted precisely because the law does not indicate special grounds for such verification.

Eurasian patent legislation (which in general has been harmonized with the internal legislation of the Russian Federation) follows the same approach, which stipulates the procedure for contesting the term of validity of a patent but not for contesting the actions of the Eurasian Patent Office in prolonging the validity of a patent.

Hence, in accordance with Regulation 16, para. 7(a) of the Patent Instructions for the Eurasian Patent Convention (adopted 1 December 1995), after the date of public notice of extension of the term of a patent until the date of expiration of that term, any person may submit an objection to the Eurasian Office concerning extension of the term of a Eurasian patent on grounds of non-compliance with the conditions for extending the term of the patent as stipulated by the legislation of a Contracting State applicable to extension of the term of a Eurasian patent. Regulation 16, para. 7(b) of the Patent Instructions for the Eurasian Patent Convention establishes that the outcome of considering an objection may be a decision either to annul the extension of the term of a Eurasian patent or to dismiss the objection. Although the grounds for contesting supplementary patents are omitted 
from legal regulation, there is no omission of the procedure for such contestation.

In accordance with Art. 11, para. 1 and Art. 1248, para. 1 and 2 CC RF; in the event that the law does not provide an administrative procedure for considering a particular dispute concerning an item of intellectual property, a judicial procedure is to be applied. Therefore, in the absence of any direct legal standard pertaining to an administrative procedure for the protection of civil rights, a judicial procedure for their protection is to be applied.

Pursuant to Art. 43.4 (2)(2)(5) of the Federal Constitutional Law dated 28 April 1995 No. 1-FKZ "On the commercial courts of the Russian Federation" and Art. 4 (2)(5) of the Commercial Procedural Code of the RF, the competent court for considering such disputes is the Intellectual Property Court. Such a dispute may be considered upon the application of an interested party (Art. 4 of the Arbitration Procedural Code of the RF).

The Presidium of the Intellectual Property Court noted that the contested patent had been extended while the previous version of Art. 1363 of the CC RF, under which no supplementary patent had been issued, was in force, but the term of validity of the basic patent was extended for a specific product. Nevertheless, there was no difference in the essence of the relationship, and there was also a gap in the legislative regulation for contesting an unlawful extension of legal protection for a specific product covered by a patent. The conditions for extending the term of a patent in Art. 1363, para. 2 of the CC RF were the same, and contesting the validity of an exclusive right (including its extension) was allowed to proceed in the same manner as in para. 5 of that article of the Code. Art. 1398, para. 1(1) CC RF also did not take into account the fact that additional conditions had been established for legal protection of the product whose legal protection had been extended.

In view of the above and with regard to the previous version of the $\mathrm{CC}$ RF, the Presidium of the Intellectual Property Court concluded that the product's legal protection, which had been extended in violation of the conditions of Art. 1363, para. 2(1) CC RF may be contested; by analogy the laws also applicable are Art. 6(1) and Art. 1398, para. 1(1) of the CC RF.

\section{Contesting the decision of Rospatent to reject in part the registration of a trademark}

The fact of registration of a trademark with respect to a portion of the goods and services for which application has been submitted does not con- 
stitute an obstacle to contesting a decision of Rospatent based on Art. 1500 of the CC RF as it pertains to rejection of registration of a trademark for other stated goods and services for which application has been submitted.

Decision of the Presidium of the IPC dated 15 October 2021 in case No. SIP-139/2021.

Rospatent reached a decision to register a trademark with respect to a portion of the goods and services for which an application had been submitted and to reject registration for the remainder of the goods and services. The applicant contested this decision to reject registration, but Rospatent refused to consider the contestation. Rospatent's reasoning based on a combined reading of Art. 1500 and 1512 of the CC RF was that Art. 1500, para. 1 of the CC RF governs only the procedure for contesting a decision on state registration of a trademark on the condition that state registration had not yet taken place, but in this instance state registration of a trademark had already taken place at the time the contestation was advanced.

The decision of the Intellectual Property Court, which was upheld without change by the Presidium of the IPC, was that Rospatent had acted unlawfully, and the Court required that administrative body to consider the applicant's contestation.

The Presidium of the IPC noted that Rospatent's decision concerning state registration of a trademark for only a portion of the goods and services for which application had been submitted in fact consisted of two parts: a decision to register a trademark for a range of goods; and a decision to reject registration of a trademark for the remainder of the goods and services. The first decision, which granted an exclusive right to the applicant, may be contested by a third party through the procedure set in Art. 1512 and 1513 of the CC RF. The second decision, whose outcome was that no exclusive right was granted, may be contested by the applicant through the procedure in Art. 1500 of the CC RF.

When an applicant is objecting to the partial rejection of registration of a trademark, invoking Art. 1512 and 1513 of the CC RF would be in error for several reasons: those articles do not specify any grounds for the actual rightholder to contest the decision; those grounds do not apply to broadening legal protection but merely to annulling it or restricting it, and in general the provisions of Art. 1512 of the CC RF may not be applied to restoration of rights which the possessor of a right regards as infringed.

Pursuant to Art. 1500 of the CC RF, the right to contest by submitting to an administrative body a challenge of a decision by Rospatent to reject 
registration of a trademark is restricted solely with respect to the deadline for submission of such a challenge (four months from the date of issuance of the decision). Any other restrictions on the right to a timely contestation would be groundless. Hence, Rospatent's reference to Regulation No. $644 / 261$, para. 13 in rejecting a contestation due to the existence of state registration of a trademark was without merit. The opinion of the Presidium was that this point presupposes the existence of state registration explicitly for specific goods and services and not of registration as such, and it does not stipulate its application to the "rejecting" portion of a decision concerning state registration of a trademark. The Presidium noted also that payment of the state fee for registration of a designation for which an application had been submitted with respect to a portion of the goods and services does not constitute grounds for rejecting consideration of a contestation of the rejection to register the designation applied for with respect to other goods and services on the basis of Art. 1500 of the CC RF. Payment of the state fee does not indicate agreement with the decision of an administrative body concerning rejection of registration of a trademark and does not impair the right to appeal such a decision.

\section{Establishing the distinctiveness of the elements of a trademark}

If Rospatent has recognized that certain designated elements are distinctive of the goods and services for which an application has been submitted, then it is bound by its findings with regard to registration of those same elements by that same applicant. In the absence of challenges from other parties, the elements that have at a certain time been recognized by Rospatent as being distinctive must thereafter be recognized by that administrative body as having that quality.

Decision of the Presidium of the IPC dated 4 October 2021 in case No. SIP-1047/2020

Rospatent rejected registration as a verbal trademark of a designation consisting of the elements ONE, PRICE, COFFEE on the grounds that the designation was not distinctive (Art. 1483, para. 1 of the CC RF). Rospatent arrived at the conclusion that this designation could be interpreted as an indication that the field of activity of the applicant connected with particular goods and services (coffee, coffee-based products, and products with a coffee aroma, as well as services to make and sell coffee at a single price or to provide coffee at a single price) and that it characterizes the goods and services which are to be individualized by the designation. 
However, an analogous combined designation had previously been registered by Rospatent as a trademark for services, including for the very same services that were applied for in the disputed designation, and therefore its distinctiveness had been recognized.

With regard to this, the Presidium of the IPC noted that, in registering other trademarks from the same party, the administrative body was bound by its findings concerning the identical elements in those trademarks. In the absence of challenges from other parties, the elements that had at a prior time been recognized by Rospatent as being distinctive must thereafter be recognized by the administrative body as having that quality.

The finding that any element of a trademark lacks distinctiveness (or that the trademark as a whole lacks distinctiveness) may be reconsidered by Rospatent exclusively through the procedure established by the CC RF for considering administrative appeals. Any other treatment would not comply with Art. 45 (1) of the Constitution of the Russian Federation.

Furthermore, the Presidium noted that the evaluation of a designation in accordance with the requirements of Art. 1483, para.1 of the CC RF must proceed from its understanding by a typical, average consumer of such goods in the Russian Federation, who is the target audience of the goods for which individualization by a trademark has been requested. The Presidium therefore deemed erroneous the reliance of the court of first instance on the opinions of persons with specialized knowledge of design and art history in evaluating the understanding of the designation. In view of the foregoing, the case was referred for reconsideration to the court of first instance.

\section{Interest in litigation of cases pertaining to unfair competition}

Legal positions concerning the interest of a plaintiff in disputes concerning trademark cancellation for lack of use are not applicable either directly or by analogy with cases pertaining to claims that acquisition of exclusive rights to a trademark constitutes unfair competition.

Registration of a trademark by a party which is affiliated to other parties whithin a group and determination among those parties themselves of the procedure for exercising the exclusive rights to that trademark is a customary commercial practice. In order to find that such a customary commercial practice is unfair, the purpose of the pertinent acts and the aim of that party's conduct must be proven.

Decision of the Presidium of the IPC dated 4 October 2021 in case No. SIP-4/2021. 
The plaintiff filed a judicial action claiming that the acts of an affiliated party in acquiring and exercising exclusive rights to a trademark for identical goods constituted unfair competition under the provisions of the Federal law on the protection of competition of 26 July 2006 No. 135-FZ, as well as abuse of rights.

The decision of the Intellectual Property Court, which was upheld without change by a decision of the Presidium of the IPC, rejected the claims. The cassation appeal was rejected due to the plaintiff's lack of an independent interest in that category of cases or of the right to an indirect claim on protection of the interests of the legal entity in which the plaintiff was a participant.

In cases pertaining to unfairly obtaining and using a trademark, current legislation does not grant a right of indirect appeal to a participant in a legal entity. With respect to the interest of that party itself, the Presidium of the Court emphasized the distinction between the essence of the legal relations incorporated in antimonopoly legislation regarding unfair competition through registration of a trademark and those pertaining to an trademark cancellation action for lack of use (Art. 1486 of the CC RF). The latter does not take into account the purpose of rightholder in registering a disputed trademark, and the interest of the plaintiff lies solely in the future. These distinctions bear on the divergent ways in which a trademark dispute may arise for each of the categories, and the legal positions pertaining to disputes on trademark cancellation for lack of use cannot be directly or by analogy applied to disputes concerning improper conduct by a defendant in obtaining and using a trademark. Therefore, the latter category of cases has no bearing on the matter of argumentation concerning the extent of a party's interest in the subsequent use of a disputed trademark, and the point to be proven is the infringement of the plaintiff's rights at the time when the defendant obtained an exclusive right. Analogous positions have been expressed in the decisions of the Presidium of the IPC dated 17 October 2016 in case No. SIP-189/2016, 16 July 2018 in case No. SIP-313/2017, 2 November 2018 in case No. SIP-795/2017, 24 June 2019 in case No. SIP$134 / 2018$ among others.

Concerning the essence of the dispute, the Presidium of the IPC noted that the plaintiff in part grounded their claim that the defendant acted in bad faith on the fact that the disputed trademark had been registered in the name of one of several affiliated legal entities for the purpose of prohibiting use of that designation by another affiliated party. The Court explained that registration of a trademark by one of the parties to an affiliation (and/or 
included in a group) and determination among those parties themselves of the procedure for exercising the exclusive rights to that trademark is a customary commercial practice. The intent to prohibit the use of the designation by another affiliated party, for example, in taking action to prevent the use of the disputed trademark did not constitute evidence of ill conduct.

\section{Conflict between rights to a trademark and to a trade name}

In order to assess whether it is inconsistent in the sense of Art. 1483, para. 8 of the CC RF to register a trademark consisting of a sign previously registered as a company name, the fact of a party's distributing the disputed goods under its own name to the public, in addition to other circumstances, is relevant rather than which party is the manufacturer of the goods. To settle such a dispute would require inquiry into the degree of likeness between the goods for which legal protection of the trademark is being requested and the goods marketed under the company name.

Decision of the Presidium of the IPC dated 20 September 2021 in case No. SIP-937/2020.

The AMAIA, LLC company contested a third party's registration of a combined trademark containing the verbal element "AmaiA" for a range of goods in Class 25 of the International Classification of Goods and Services (clothing). The company alleged violation of Art. 1483, para. 1(3) and para. 8 of the CC RF because the company's registration of its company name had taken place prior to the date of priority for the trademark and because that name was already well recognized in the clothing market. Rospatent dismissed the contestation and made reference to the following: the party bringing the contestation does not manufacture goods of Class 25 of the International Classification of Goods and Services but conducts sales activities that correspond to services of Class 35 of the International Classification of Goods and Services; its retail outlets sell clothing of the foreign brand AMAIA, and the materials presented in the case do not demonstrate any connection between the company and the manufacturer of the clothing.

The decision of the Rospatent was annulled by judgment of the Intellectual Property Court, as upheld by the Presidium of the IPC, on the basis of the following two findings.

First, the Intellectual Property Court stated that the identity of the manufacturer of the clothing sold by the company under its company name has no legal bearing on the proper resolution of the dispute. The Presidium 
of the IPC called attention to the set of circumstances that in established practice must be determined in order to resolve the matter of a conflict between registration of a designation as a trademark when there is an opposing company name. The Court noted that the identity of the manufacturer of the products sold under the countervailing company name is not among these circumstances. What is relevant to the matter is the fact itself that the company introduced Class 25 goods, or goods similar to them, into commerce under its company name.

Second, the Intellectual Property Court specified that Rospatent wrongfully declined to investigate the degree of similarity of the clothing sold by the company to goods of Class 25 of the International Classification of Goods and Services, for which the disputed trademark had been issued.

\section{Information about the authors:}

N.I. Kapyrina - PhD, Assistant Professor;

M.A. Kolzdorf - LL.M., Lecturer.

\section{Contribution of the authors:}

N.I. Kapyrina - part 2,4,5;

M.A. Kolzdorf - part 1,3.

The article was submitted 30.09.2021; approved after reviewing 15.10.2021; accepted for publication 18.10.2021. 